\title{
Prevalence and risk factors of anemia in children aged from 6 to 59 months in Togo: analysis from Togo demographic and health survey data, 2013-2014
}

\author{
Aboubakari Nambiema $^{1 *}$ D, Alexie Robert ${ }^{2}$ and Issifou Yaya ${ }^{1}$
}

\begin{abstract}
Background: Anemia in children continues to be a major public health challenge in developing countries and particularly in Sub-Saharan Africa. Anemia has serious consequences on the growth and development of the children in the early stages of life. This study aimed to determine the prevalence and associated factors of anemia among children from 6 to 59 months in Togo.

Methods: Data from the Togo Demographic and Health Survey 2013-2014 were used for this study. This nationally representative survey provided data on a wide range of indicators such as mother and child health, nutrition and other characteristics. Anemia status was determined using hemoglobin level $(\mathrm{Hb}<11.0 \mathrm{~g} / \mathrm{dl})$, and the weighted prevalence of childhood anemia along with 95\% confidence intervals were provided. Data were analyzed using logistic regression models to estimate odds ratios (OR) and their $95 \%$ confidence intervals ( $95 \%$ Cl) for associated factors.

Results: Two thousand eight hundred ninety children aged 6-59 months were included in this analysis. The weighted prevalence of anemia was $70.9 \%[95 \% \mathrm{Cl}=68.8-73.1]$ with $2.6 \%[95 \% \mathrm{Cl}=2.0-3.3]$ of severe anemia among these children. In the multivariate analysis, the adjusted odds ratio (aOR) for anemia was 0.33 [95\% Cl=0.26-0.42] in children aged from 24 to 42 months and 0.22 [95\% Cl=0.17-0.29] in children aged from 43 to 59 months. Children's malaria status was strongly associated to childhood anemia with an aOR of $3.03[95 \% \mathrm{Cl}=2.49-3.68]$. The secondary level of education and more for the mother was associated to childhood anemia with an aOR of 0.67 [ $95 \% \mathrm{Cl}=0.52-0.86]$. The aOR for children whose mother had anemia was $1.62[95 \% \mathrm{Cl}=1.30-2.02]$.

Conclusion: This study has highlighted the high prevalence of childhood anemia in Togo and revealed that younger children and maternal anemia were positively associated to childhood anemia whereas age of children and high level of maternal education were negatively associated to childhood anemia.
\end{abstract}

Keywords: Anemia, Prevalence, Risk factors, Children, Togo

\section{Background}

According to the World Health Organization (WHO), anemia is one of the ten most serious health problems in the world [1]. Frequently observed among children aged 6 to 59 months and in pregnant women who are the most vulnerable group, anemia is defined as a hemoglobin level below $11.0 \mathrm{~g} / \mathrm{dl}[1,2]$. It corresponds to a state in

\footnotetext{
* Correspondence: aboubakar.net@gmail.com

${ }^{1}$ Centre Africain de Recherche en Epidémiologie et en Santé Publique (CARESP), Lomé, Togo

Full list of author information is available at the end of the article
}

which the number of red blood cells is low, or their ability to carry oxygen (i.e. hemoglobin) is so poor, in order to satisfy the physiological needs of the organism. In 2011, the WHO [2] estimated that about 273.2 million children aged from 6 to 59 months in the world were suffering from anemia, with an overall prevalence of $42.6 \%$. However, this disproportionately affects the regions of the world. Sheltering approximately 84.5 million 6-59 months aged children suffering from anemia, Sub-Saharan Africa remains the most affected region with a prevalence reaching $62.3 \%$.

(c) The Author(s). 2019 Open Access This article is distributed under the terms of the Creative Commons Attribution 4.0 International License (http://creativecommons.org/licenses/by/4.0/), which permits unrestricted use, distribution, and reproduction in any medium, provided you give appropriate credit to the original author(s) and the source, provide a link to the Creative Commons license, and indicate if changes were made. The Creative Commons Public Domain Dedication waiver (http://creativecommons.org/publicdomain/zero/1.0/) applies to the data made available in this article, unless otherwise stated. 
The early treatment of anemia and its eradication are a public health goal as well as a major school challenge because it could not only improve growth, but also the intellectual capacities of children [3]. Indeed, the consequences of the anemia among preschoolers are serious [4-7] and include: impairment of cognitive function, impaired motor development and growth, declining academic performance, decreased immune function which exposes children to infections, decreased responsiveness and activity, and fatigue. These can irreversibly compromise the future development of a child. This situation has awoken a particular interest both nationally and internationally, leading to the implementation of prevention programs through food fortification and intermittent iron supplementation $[8,9]$.

However, the success of these community programs in Sub-Saharan Africa require a good knowledge of the risk factors of anemia. Several studies have been conducted in this area [10-13] and showed that anemia is present in 60.2 to $87.8 \%$ of children from 6 to 59 months. They highlighted a link between anemia among preschoolers and several factors including individual (age, childhood malaria, female sex), maternal (educational level) and contextual characteristics such as household income, living environment (urban/rural). A study based on data from Demographic and Health Survey (DHS) of 11 African french-speaking countries [10] showed that protein-energy malnutrition strongly contributed to the occurrence of anemia among children. In another study conducted in Ghana, the prevalence of anemia was high among preschool children aged less than 2 years [11]. In a recent study of anemia risk factors in children aged 6-59 months in sub-Saharan Africa, Moschovis et al. [14] found associations between child anemia and individual (age, female sex, birth order), maternal (maternal anemia, mother's age mother's body mass index) and contextual (household income, family structure) characteristics of the child.

In Togo, the 2013-2014 DHS revealed that the prevalence of anemia among children aged from 6 to 59 months was also high and anemia affected about 70.0\% of these children, of which $2.0 \%$ were suffering from a severe form [15]. With a prevalence higher than $40.0 \%$, WHO considers anemia in children $6-59$ months as a severe public health problem $[1,16]$. Furthermore, Togo is part of the African region where the prevalence of anemia among children aged 6 to 59 months has been estimated at over 72\% [10]. Nevertheless, apart from some studies conducted in hospital settings $[17,18]$, the topic of anemia in children aged $6-59$ months is mostly unexplored at the national level in Togo.

This study aimed to determine the prevalence and associated factors of anemia among children aged from 6 to 59 months in Togo. This study on the risk factors of anemia in children aged from 6 to 59 months is the first of its kind in Togo, and can provide reliable information to help develop new strategies for the prevention of anemia among the children in this country.

\section{Methods}

The data used in this study is extracted from the third Togo Demographic and Health Survey (DHS-III) conducted in 2013-2014. DHS-III is part of the DHS program, led by the United States Agency for International Development (USAID), which has been conducting household surveys in developing countries since 1984 [19]. Details about the survey can be found in the 2013-2014 DHS report [15]. DHS are regularly conducted among large samples of households' representative of the population of each country. Their goal is to provide governments with recent and reliable information on population health indicators in order to allow for adaptation of health policies. One of the major interests of these surveys is the homogeneity of their methodology in different countries, which permits in most cases, to compare situations and obtain a global vision [10]. The DHS deals with many health issues, including reproduction, child health (breastfeeding and nutrition, vaccinations, anemia, acute respiratory infections and diarrhea), malaria and the Human Immunodeficiency Virus (HIV) [15].

According to the Report of the DHS 2013-2014 in Togo [15], the DHS-III aims to produce results representative of the whole country, of separate urban and rural environments, from the city of Lomé (the capital city of Togo), and from each of the five regions of Togo.

As anemia has a high prevalence in children under 5 years old, and causes serious impairment to the development of preschoolers, we limited our study to the age group of 6-59 months old. In the Togo DHS 2013-2014, 3378 children between 6 and 59 months were evaluated. Of these, 2890 children had anemia test results, and were included in the study". Survey weights were used in analyses in order to account for the unequal probability of selection of households induced by the sampling scheme and non-response. A detailed explanation of the weighting procedure can be found in the Demographic and Health Survey Methodology report [20].

\section{Outcome variable}

During the DHS-III, anemia was tested by performing blood samples in every second household in the study population. The tests were performed using a portable hemoglobin meter (HemoCue) device which, in less than a minute, could give the hemoglobin level in grams per deciliter of blood, and finally allow to record the value in the questionnaire [10].

According to $\mathrm{WHO}$, in children aged from 6 months to 5 years old, a hemoglobin concentration level below $11.0 \mathrm{~g} / \mathrm{dl}$ corresponds to anemia, a level below $7.0 \mathrm{~g} / \mathrm{dl}$ is 
considered as severe anemia, a level between $7.0 \mathrm{~g} / \mathrm{dl}$ and $9.9 \mathrm{~g} / \mathrm{dl}$ is considered as moderate anemia and a level between $10.0 \mathrm{~g} / \mathrm{dl}$ and $10.9 \mathrm{~g} / \mathrm{dl}$ is considered as mild anemia [2]. Thus, the dependent variable was coded into two levels. A child was classified as anemic if his hemoglobin level was below the WHO threshold of $11.0 \mathrm{~g} / \mathrm{dl}$.

\section{Independent variables}

\section{Variables related to child's characteristics}

Among the selected independent variables, some were related to the child such as sex, age (divided into three categories: 6-23 months, 24-42 months and 43-59 months), taking iron supplements, nutritional status and malaria diagnosis.

Nutritional status was estimated from anthropometric measures of height and weight of the child. For each individual, his height / weight ratio was compared to the median for the population. From this, nutritional status was divided into three categories. A detailed explanation of the procedure can be found in the Reference Guide on Nutrition Indicators for Development [21]. Thus, if an individual had a standard deviation lower than -2 , he was considered as malnourished; if the standard deviation was between -2 and 2, he was considered as normal and if the standard deviation was greater than 2 , he was considered as overweight.

Malaria diagnosis was made using the rapid diagnostic test which gave a result either positive meaning that the child had malaria or negative if the child did not have malaria [10].

\section{Variables related to the child's mother}

Variables relating to the child's mother were also selected: anemia (anemic or not), educational level (no education, primary or secondary school level and above) and economic activity (currently working or have worked in the last 12 months, not working).

\section{Variables related to household characteristics}

The child's household income, region of residence, place of residence (urban/rural) and whether or not his father was alive were included in the statistical analysis.

\section{Statistical analysis}

We conducted descriptive data analysis in order to describe the main characteristics of our sub-sample of young Togolese children suffering from anemia. In these analyses, we performed Chi-Square test of Rao-Scott to determine whether there was a significant difference between observed and expected frequencies.

To evaluate the effect of each of individual, maternal and contextual characteristics on anemia in Togolese children aged from 6 to 59 months old, logistic regression models were used to estimate odds ratios (ORs) and their 95\% confidence intervals (95\% CI).

The association between the independent variables and anemia in the children were first examined using bivariate logistic regression. All significant variables with $p$-value of Wald test less than 0.20 were included in the multivariate model. The non-significant variables in the bivariate analysis whose associations with anemia had been shown in the literature were also introduced into the multivariate regression models. The final model was obtained using a manual variable selection method based on the $p$-value in order to obtain the parsimonious model.

All analyses were performed using SAS (Statistical Analysis Software) version 9.4.

\section{Results}

\section{Characteristics of study population}

Two thousand eight hundred and ninety (2890) children aged 6-59 months were included in this analysis. Children aged 6-23 months were the most represented (36.3\%). The proportion of boys and girls in the sample was similar with respectively 1456 (50.4\%) and 1434 (49.6\%). Two thousand and eighty-five (2085) children (72.6\%) had not taken iron supplements and 213 (7.4\%) of them were malnourished. During the survey more than one-third of the children, 1067 (37.0\%) were tested positive for malaria.

Overall, 1522 children (52.7\%) lived in poor household and 2111 children $(73.0 \%)$ in the rural areas. Almost a quarter of the children, 701 (24.3\%), in the sample were from the Savanes region. Most children's, 2824 (97.8\%) fathers were alive during the survey.

Concerning the characteristics of the children's mothers, 1345 mothers $(46.5 \%)$ had no education whereas 556 (19.2\%) attended secondary school or more. Most of mothers (85.5\%) were employed and 1232 mothers (42.8\%) had anemia (Table 1).

\section{Prevalence of anemia}

The overall prevalence of anemia among children aged from 6 to 59 months was $70.9 \%$ [95\% CI $=68.8-73.1]$ of which $25.6 \%$ [95\% CI $=23.7-27.5]$ had mild anemia, 42.7\% [95\% CI $=40.4-45.0]$ had moderate anemia and $2.6 \%[95 \% \mathrm{CI}=2.0-3.3]$ had severe anemia. Table 1 provides the characteristics of children, their mother, their household, and the distribution of anemia across child related factors, maternal factors and household factors. A higher proportion of anemia was observed among children younger than 24 months $(84.0 \%$ [95\% CI $=$ 81.4-86.5]; $p<0.0001)$, malnourished $(80.6 \%$ [95\% CI $=$ $74.8-86.3] ; p=0.0059)$, and suffering from malaria $(82.4 \%$ [95\% CI $=79.9-84.9] ; p<0.0001$ ). We also observed higher proportion of anemia in children whose mothers suffered from anemia (75.8\% [95\% CI $=72.8-78.7] ; p<0.0001)$ or 
Table 1 Prevalence of anemia (\%) among Togolese children aged 6-59 months by demographic and household characteristics

\begin{tabular}{|c|c|c|c|c|c|}
\hline Factors & n (\%) & Anemia (n) & $\begin{array}{l}\text { Unweighted Prevalence } \\
\text { of anemia [95\% Cl] }\end{array}$ & $\begin{array}{l}\text { Weighted Prevalence of } \\
\text { anemia }[95 \% \mathrm{Cl}]\end{array}$ & $p$-value \\
\hline Total & $2890(100.0)$ & 2052 & $71.0[69.0-73.0]$ & $70.9[68.8-73.1]$ & \\
\hline \multicolumn{6}{|l|}{ Child related factors } \\
\hline Sex of children & & & & & 0.2863 \\
\hline Male & $1456(50.4)$ & 1049 & $72.0[69.7-74.7]$ & $71.9[69.1-74.8]$ & \\
\hline Female & $1434(49.6)$ & 1003 & $69.9[67.3-72.6]$ & $69.9[67.1-72.7]$ & \\
\hline Age of children & & & & & $<0.0001$ \\
\hline 6-23 months & $1048(36.3)$ & 887 & $84.6[82.4-86.9]$ & $84.0[81.4-86.5]$ & \\
\hline 24-42 months & $987(34.1)$ & 660 & 66.9 [63.9-69.8] & $66.4[63.4-69.5]$ & \\
\hline 43-59 months & 855 (29.6) & 505 & $59.1[55.3-62.9]$ & $59.7[55.4-63.9]$ & \\
\hline Nutritional status & & & & & 0.0059 \\
\hline Malnourished & $213(7.4)$ & 171 & $80.3[74.9-85.7]$ & $80.6[74.8-86.3]$ & \\
\hline Normal & $2606(90.2)$ & 1826 & $70.1[68.0-72.2]$ & $70.0[67.7-72.3]$ & \\
\hline Overweight & $71(2.4)$ & 55 & $77.5[67.7-87.2]$ & $77.4[67.1-87.7]$ & \\
\hline Iron supplements intake & & & & & 0.4983 \\
\hline No & $2085(72.6)$ & 1494 & $71.7[69.4-73.9]$ & $71.4[68.9-73.9]$ & \\
\hline Yes & $788(27.4)$ & 547 & $69.4[65.8-73.1]$ & $69.8[65.7-73.8]$ & \\
\hline Children had malaria & & & & & $<0.0001$ \\
\hline No & $1820(63.0)$ & 1173 & $64.5[62.0-66.9]$ & $64.5[61.9-67.2]$ & \\
\hline Yes & $1067(37.0)$ & 876 & $82.1[79.7-84.5]$ & 82.4 [79.9-84.9] & \\
\hline \multicolumn{6}{|l|}{ Maternal factors } \\
\hline Mother's education status & & & & & $<0.0001$ \\
\hline No education & $1345(46.5)$ & 990 & $73.6[70.8-76.4]$ & $74.2[71.1-77.2]$ & \\
\hline Primary & $989(34.2)$ & 710 & $71.8[68.8-74.8]$ & $72.7[69.3-76.0]$ & \\
\hline Secondary and more & $556(19.2)$ & 352 & $63.3[59.1-67.5]$ & $61.6[57.4-65.9]$ & \\
\hline Mother's occupation status & & & & & 0.1650 \\
\hline Not working & $419(14.5)$ & 309 & $73.7[69.4-78.1]$ & $73.969 .3-78.5]$ & \\
\hline Working & $2470(85.5)$ & 1742 & $70.5[68.4-72.7]$ & $70.4[68.1-72.7]$ & \\
\hline Mother's anemia status & & & & & $<0.0001$ \\
\hline No & $1649(57.2)$ & 1104 & $66.9[64.3-69.6]$ & 66.9 [63.9-69.9] & \\
\hline Yes & $1232(42.8)$ & 940 & $76.3[73.8-78.8]$ & $75.8[72.8-78.7]$ & \\
\hline \multicolumn{6}{|l|}{ Household factors } \\
\hline Wealth index & & & & & $<0.0001$ \\
\hline Poor & $1522(52.7)$ & 1107 & $72.7[70.0-75.5]$ & $74.2[71.4-77.1]$ & \\
\hline Middle & $528(18.3)$ & 397 & $75.2[71.1-79.3]$ & $74.6[70.3-79.0]$ & \\
\hline Rich & $840(29.1)$ & 548 & $65.2[61.5-68.9]$ & $65.2[61.4-69.0]$ & \\
\hline Father's alive & & & & & 0.7447 \\
\hline No & $64(2.2)$ & 45 & $70.3[59.7-80.9]$ & $69.0[56.9-81.1]$ & \\
\hline Yes & $2824(97.8)$ & 2006 & $71.0[69.0-73.0]$ & $71.0[68.8-73.2]$ & \\
\hline Place of residence & & & & & 0.0002 \\
\hline Rural & $2111(73.0)$ & 1542 & $73.0[70.7-75.4]$ & $73.9[71.4-76.4]$ & \\
\hline Urban & $779(27.0)$ & 510 & $65.5[61.6-69.3]$ & $65.3[61.4-69.2]$ & \\
\hline
\end{tabular}


Table 1 Prevalence of anemia (\%) among Togolese children aged 6-59 months by demographic and household characteristics (Continued)

\begin{tabular}{|c|c|c|c|c|c|}
\hline Factors & n (\%) & Anemia (n) & $\begin{array}{l}\text { Unweighted Prevalence } \\
\text { of anemia [95\% Cl] }\end{array}$ & $\begin{array}{l}\text { Weighted Prevalence of } \\
\text { anemia }[95 \% \mathrm{Cl}]\end{array}$ & $p$-value \\
\hline Region of residence & & & & & 0.0259 \\
\hline Savanes & $701(24.2)$ & 478 & $68.2[63.6-72.8]$ & $69.2[64.4-74.0]$ & \\
\hline Kara & $434(15.0)$ & 336 & $77.4[72.7-82.1]$ & $77.0[71.9-82.2]$ & \\
\hline Centrale & $412(14.2)$ & 306 & $74.3[69.6-79.0]$ & $74.5[69.6-79.4]$ & \\
\hline Plateaux & $519(18.0)$ & 380 & $73.2[68.9-77.5]$ & $73.2[69.3-77.2]$ & \\
\hline Maritime (without Lomé) & $334(11.6)$ & 234 & $70.1[63.9-76.3]$ & $69.8[62.9-76.7]$ & \\
\hline Lomé town & $490(17.0)$ & 318 & $64.9[60.2-69.6]$ & $65.6[61.1-70.0]$ & \\
\hline
\end{tabular}

$p$-value: the $p$-value of Chi-Square Rao-Scott test

had no education (74.2\% [95\% CI $=71.1-77.2] ; p<0.0001)$. In addition, this proportion was also significantly higher for children who lived in rural areas $(73.9 \%[95 \% \mathrm{CI}=$ $71.4-76.4] ; p=0.0002)$ or in the Kara region $(77.0 \%$ [95\% CI $=71.9-82.2] ; p=0.0259)$ (Table 1 ).

\section{Factors associated with anemia}

Table 2 shows results of bivariate and multivariate analyses for assessing associations between childhood anemia and potential risk factors.

In bivariate analysis, we found that the following variables were associated with childhood anemia (Model 1): age of children, child nutritional status, child malaria status, mother's education, mother's anemia status, household wealth index, place of residence and region of residence. No association was apparent between childhood anemia and sex of children, taking iron supplements, mother's occupation status or whether or not the child's father was alive.

Model 2 in Table 2 shows the odds ratios from multivariate logistic regression for assessing associations between different factors and anemia among children aged 6-59 months in Togo. The child's late age and his mother's high-level education were negatively associated to childhood anemia whereas malaria in the child and anemia in his mother were positively associated to childhood anemia. The adjusted odds ratio (aOR) for anemia was $0.33[95 \% \mathrm{CI}=0.26-0.42]$ in children aged from 24 to 42 months and 0.22 [95\% CI $=0.17-0.29]$ in children aged from 43 to 59 months. The OR for anemia was three times higher in children with malaria compared to those without anemia $(\mathrm{aOR}=3.03[95 \% \mathrm{CI}=2.49-3.68]$ ). The odds of childhood anemia among children whose mothers had anemia was higher compared to those whose mothers did not have anemia $(\mathrm{aOR}=1.62[95 \%$ $\mathrm{CI}=1.30-2.02]$ ). Concerning mother's education, we observed that secondary level education or more was negatively associated with the childhood anemia $(\mathrm{aOR}=0.67$ $[95 \% \mathrm{CI}=0.52-0.86])$. The sex of children, their nutritional status, whether or not they took iron supplements and all household factors were not associated with childhood anemia in the multivariate model.

\section{Discussion}

This study adds evidence to the literature concerning prevalence and risk factors of childhood anemia in SubSaharan Africa countries.

To the best of our knowledge, this is the first study in Togo estimating prevalence and risk factors of anemia in children aged from 6 to 59 months. The results of this study have shown a high prevalence of anemia among Togolese children aged from 6 to 59 months, making this a serious public health issue $[1,16]$. In Togo, staple foods consist of corn, millet, cassava and rice which are rich in carbohydrates. This low diversification of food substitutes along with a low iron-rich diet could explain this high rate of anemia despite the high rates of breastfeeding. Moreover, there are rarely specific food formulas that account for the nutritional needs of the child. Previous studies have shown similar results ranging from $72.4 \%$ in 11 French-speaking African countries to $78.4 \%$ in Ghana [10, 18, 22].

When examining associations between risk factors and childhood anemia, we showed that anemia was associated with both characteristics of the child and those of his mother. The negative association between the age of the child and anemia has been showed by Ngesa and Mwambi who reported a lower risk of anemia in older children [23]. Magalhães and Clements [13] in a National cross-sectional household-based demographic health surveys in West Africa reported the same trend of anemia prevalence by age. This could be explained by the fact that children who are getting older receive a diet which is richer and complete, with a sufficient intake of iron which could prevent the occurrence of anemia in the child.

Concerning the child's malaria status, those who had malaria were found to have higher risk of anemia as compared to their counterparts who did not have malaria. Increased hemolysis or decreased red blood cell production rates, could explain the higher risk of anemia among 
Table 2 Factors associated with anemia in children aged 6-59 months in Togo

\begin{tabular}{|c|c|c|c|c|}
\hline \multirow[t]{2}{*}{ Factors } & \multicolumn{2}{|l|}{ Model 1} & \multicolumn{2}{|l|}{ Model 2} \\
\hline & COR $[95 \% \mathrm{Cl}]$ & $\mathrm{pW}$ & $\mathrm{aOR}[95 \% \mathrm{Cl}]$ & $\mathrm{pW}$ \\
\hline \multicolumn{5}{|l|}{ Child related factors } \\
\hline Sex of children & & 0.3281 & & \\
\hline Male & 1.00 & & - & \\
\hline Female & $0.91[0.76-1.09]$ & & - & \\
\hline Age of children & & $<0.0001$ & & $<0.0001$ \\
\hline 6-23 months & 1.00 & & 1.00 & \\
\hline 24-42 months & $0.38[0.30-0.47]$ & & $0.33[0.26-0.42]$ & \\
\hline 43-59 months & $0.29[0.22-0.37]$ & & $0.22[0.17-0.29]$ & \\
\hline Nutritional status & & 0.0048 & & \\
\hline Normal & 1.00 & & - & \\
\hline Malnourished & $1.82[1.23-2.70]$ & & - & \\
\hline Overweight & $1.45[0.80-2.64]$ & & - & \\
\hline Iron supplements intake & & 0.5753 & & \\
\hline No & 1.00 & & - & \\
\hline Yes & $0.94[0.75-1.18]$ & & - & \\
\hline Children had malaria & & $<0.0001$ & & $<0.0001$ \\
\hline No & 1.00 & & 1.00 & \\
\hline Yes & $2.55[2.12-3.07]$ & & $3.03[2.49-3.68]$ & \\
\hline \multicolumn{5}{|l|}{ Maternal factors } \\
\hline Mother's education status & & $<0.0001$ & & 0.0027 \\
\hline No education & 1.00 & & 1.00 & \\
\hline Primary & $0.94[0.75-1.17]$ & & $1.01[0.80-1.28]$ & \\
\hline Secondary and more & $0.56[0.45-0.71]$ & & $0.67[0.52-0.86]$ & \\
\hline Mother's occupation status & & 0.1749 & & \\
\hline Not working & 1.00 & & - & \\
\hline Working & $0.84[0.66-1.08]$ & & - & \\
\hline Mother's anemia status & & $<0.0001$ & & $<0.0001$ \\
\hline No & 1.00 & & 1.00 & \\
\hline Yes & 1.53 [1.24-1.89] & & 1.62 [1.30-2.02] & \\
\hline \multicolumn{5}{|l|}{ Household factors } \\
\hline Wealth index & & 0.0003 & & \\
\hline Poor & 1.00 & & - & \\
\hline Middle & $1.02[0.79-1.32]$ & & - & \\
\hline Rich & $0.65[0.52-0.81]$ & & - & \\
\hline Father's alive & & 0.6838 & & \\
\hline No & 1.00 & & - & \\
\hline Yes & $1.13[0.63-2.00]$ & & - & \\
\hline Place of residence & & 0.0002 & & \\
\hline Rural & 1.00 & & - & \\
\hline Urban & 0.66 [0.53-0.82] & & - & \\
\hline Region of residence & & 0.0104 & & \\
\hline Savanes & 1.00 & & - & \\
\hline Kara & 1.31 [1.03-2.16] & & - & \\
\hline
\end{tabular}


Table 2 Factors associated with anemia in children aged 6-59 months in Togo (Continued)

\begin{tabular}{|c|c|c|c|c|}
\hline \multirow[t]{2}{*}{ Factors } & \multicolumn{2}{|l|}{ Model 1} & \multicolumn{2}{|l|}{ Model 2} \\
\hline & COR $[95 \% \mathrm{Cl}]$ & $\mathrm{pW}$ & $\mathrm{aOR}[95 \% \mathrm{Cl}]$ & $\mathrm{pW}$ \\
\hline Centrale & $1.49[0.92-1.86]$ & & - & \\
\hline Plateaux & $1.21[0.89-1.64]$ & & - & \\
\hline Maritime (without Lomé) & $1.03[0.69-1.53]$ & & - & \\
\hline Lomé town & $0.84[0.62-1.13]$ & & - & \\
\hline
\end{tabular}

pW: $p$ value of Wald's Chi-Square test cOR: crude OR aOR: adjusted OR 95\% Cl: 95\% confidence interval

malaria patients compared to non-malaria patients [24]. Similar results have been reported in several other studies [23, 25, 26]. Regarding iron intake, our results did not show association between iron supplements intake and childhood anemia, unlike the literature. This may be due to the fact that children did not take iron supplements continuously or that the amount which was taken by the children was low. However, the quantity of iron was not also indicated because the DHS study did not provide information concerning iron supplementation. As we lacked this information on iron supplementation, it could be biased to conclude on the effectiveness of this strategy. Therefore, there is a need to rethink how to integrate iron supplementation of children under 5 into dietary habits. In addition to this, there is no specific public health policy in Togo to prevent anemia, however, in most of the time, iron supplementation is proposed as an adjuvant treatment during the therapeutic management of malaria in children.

Regarding the mother's characteristics, we found that the mother's education level was negatively associated with anemia in children. Indeed, children whose mothers had a secondary school education level or higher were less likely to be anemic. These results were in similar to the results of previous studies on the effect of maternal schooling on children's anemia [23, 27]. Mothers with a high level of education are more likely to know about good dietary practices and take into account the nutritional values of foods. Moreover, they understand better and provide a healthy and hygienic diet for their children.

As for the relationship between anemia in the child and anemia in his mother, our study showed that, maternal anemia was consistently associated with the occurrence of child anemia. This finding can be explained by the fact that mothers and their children most often share a common environment, which could involve common exposures to some risk factors. Similar findings were observed in other studies [27, 28]. Furthermore, Al-Qaoud and colleagues [29] also showed this association among mothers of Kuwaiti preschool children.

The present study has some limitations that should be noted. The study design does not allow for cause-and-effect relationships to be established. In addition, we did not have data on child nutrition such as frequency of fruit, vegetable and meat consumption, which is important for a better understanding of the epidemiology of childhood anemia. The use of capillary blood in the place of venous samples may introduce a source of bias owing to the possibility of hemoglobin dilution with extracellular fluid through manipulation of the subject's finger when the technician pricks the skin to collect the blood drop. Despite the limitations of this technique, it has great recognized practical advantages and does not compromise the quality of diagnosis at the population level [30, 31].

This study has some strengths. The results are generalizable to the whole country. Indeed, we used representative survey data based on a validated questionnaire and methodology [20]. Moreover, these results appear consistent with the literature and is the first study in Togo examined prevalence and risk factors of anemia in children from 6 to 59 months.

Since anemia in children under 5 is considered a public health problem and WHO recommends iron supplementation, particularly for children 6 to 23 months of age, we could make the following recommendations to Togolese government based on the results of this study: Government must strengthen iron supplementation interventions targeting young children and those suffering from malaria. Interventions are also recommended to encourage populations to diversify children's foods or to enrich them with iron.

\section{Conclusion}

This study has highlighted a high prevalence of childhood anemia in Togo. The findings showed regional differences in the prevalence of anemia among children, with the highest rate being observed in the North region of the country as in Kara region. The results from this study have shown that malaria in children and maternal anemia were positively associated to childhood anemia whereas age of children and high level of maternal education were negatively associated to childhood anemia. In terms of public health, the results of the present study could help to improve the targeting of interventions that integrate and take into account identified risk factors, particularly among children under five years of age. 


\section{Abbreviations}

95\% Cl: 95\% confidence intervals; aOR: Adjusted odds ratio; cOR: Crude odds ratio; DHS: Demographic and Health Surveys; Hb: Hemoglobin; HIV: Human Immunodeficiency Virus; USAID: United States Agency for International Development; WHO: World Health Organization

\section{Acknowledgments}

The authors thank ICF International for implementing the MEASURE DHS and making the data available for public use. United States Agency for International Development (USAID) funded the MEASURE DHS project. We also thank Mr. Nicolas Pech who provided us methodological quidance and Dr. Aude Laetitia Ndoadoumgue for improving the use of English in the manuscript.

\section{Funding}

Not applicable.

\section{Availability of data and materials}

The datasets analyzed during the current study are available in the [DHS Program] repository, [https://dhsprogram.com/Data/].

\section{Authors' contributions}

AN, AR and IY participated in the conception of the study and performed the statistical analysis. AN drafted the first version of the manuscript. All authors participated in the critical review of the manuscript and approved the final manuscript.

\section{Ethics approval and consent to participate}

No ethical approval was needed for this study because the anonymous data, with no personal identifier or link, was received from the DHS program.

\section{Consent for publication}

Not applicable.

\section{Competing interests}

The authors declare that they have no competing interests.

\section{Publisher's Note}

Springer Nature remains neutral with regard to jurisdictional claims in published maps and institutional affiliations.

\section{Author details}

'Centre Africain de Recherche en Epidémiologie et en Santé Publique (CARESP), Lomé, Togo. ${ }^{2}$ Aix-Marseille Université, Marseille, France.

\section{Received: 10 August 2018 Accepted: 14 February 2019} Published online: 20 February 2019

\section{References}

1. Sanou D, Turgeon-O'Brien H, Desrosiers T. Prévalence et déterminants non alimentaires de l'anémie et de la carence en fer chez des orphelins et enfants vulnérables d'âge préscolaire du Burkina-Faso. Nutr Clin Métabolisme. 2008:22(1):10-9.

2. WHO. Haemoglobin concentrations for the diagnosis of anaemia and assessment of severity. Vitamin and Mineral Nutrition Information System. Geneva, World Health Organization 2011. (WHO/NMH/NHD/MNM/11.1 http:// www.who.int/vmnis/indicators/haemoglobin.pdf) (accessed 3 Dec 2017)

3. Grantham-McGregor S, Ani C. A review of studies on the effect of iron deficiency on cognitive development in children. J Nutr. 2001;131(2):649S-68S.

4. Beard JL. Iron biology in immune function, muscle metabolism and neuronal functioning. J Nutr. 2001;131(2):568S-80S.

5. Lozoff B, Smith JB, Clark KM, Gloria Perales C, Rivera F, Castillo M. Home intervention improves cognitive and social-emotional scores in Irondeficient anemic infants. PEDIATRICS. 2010;126(4):e884-94.

6. McCann JC, Ames BN. An overview of evidence for a causal relation between iron deficiency during development and deficits in cognitive or behavioral function. Am J Clin Nutr. 2007:85(4):931-45.

7. Stoltzfus RJ. Iron interventions for women and children in low-income countries. J Nutr. 2011:141(4):756S-62S.

8. OMS. Directive: utilisation d'associations de micronutriments en poudre pour l'enrichissement à domicile de l'alimentation des nourrissons et des enfants de 6 à 23 mois. 2012.
9. Sylvetsky AC, Jefferds MED, De-Regil LM, Dowswell T. Intermittent iron supplementation for improving nutrition and developmental outcomes in children. In: The Cochrane Collaboration, editor. Cochrane Database of Systematic Reviews. Chichester: John Wiley \& Sons, Ltd; 2011. https://doi.org/10.1002/14651858.CD009085.

10. Diouf S, Folquet M, Mbofung K, Ndiaye O, Brou K, Dupont C, et al. Prévalence et déterminants de l'anémie chez le jeune enfant en Afrique francophone - Implication de la carence en fer. Arch Pédiatrie. 2015;22(11): 1188-97.

11. Ewusie JE, Ahiadeke C, Beyene J, Hamid JS. Prevalence of anemia among under-5 children in the Ghanaian population: estimates from the Ghana demographic and health survey. BMC Public Health. 2014;14(1). https://doi. org/10.1186/1471-2458-14-626

12. Gayawan E, Arogundade ED, Adebayo SB. Possible determinants and spatial patterns of anaemia among young children in Nigeria: a Bayesian semiparametric modelling. Int Health. 2014;6(1):35-45.

13. Magalhães RJS, Clements ACA. Mapping the risk of Anaemia in preschoolage children: the contribution of malnutrition, malaria, and helminth infections in West Africa. PLoS Med. 2011:8(6):e1000438.

14. Moschovis PP, Wiens MO, Arlington L, Antsygina O, Hayden D, Dzik W, et al. Individual, maternal and household risk factors for anaemia among young children in sub-Saharan Africa: a cross-sectional study. BMJ Open. 2018;8(5): e019654.

15. Ministère de la Planification, du Développement et de l'Aménagement du Territoire, Direction Générale de la Statistique et de la Comptabilité Nationale (DGSCN), Ministère de la Santé (MS) et ICF International. Enquête Démographique et de Santé au Togo 2013-2014. Rockville, Maryland, USA : MPDAT, MS et ICF International. Rapport disponible à l'adresse https:/dhsprogram.com/pubs/pdf/FR301/FR301.pdf, 2015 https:/dhsprogram. com/pubs/pdf/FR301/FR301.pdf (accessed 3 Dec 2017).

16. WHO. The global prevalence of anaemia in. 2011:2015.

17. Gbadoé A-D, Lawson-Evi K, Badayodi A, Géraldo A, Guédénon J, Akpako P, et al. Paludisme grave de l'enfant : évaluation de la prise en charge des formes anémiques et neurologiques dans un service de réanimation en milieu tropical. Arch Pédiatrie. 2006;13(12):1554-5.

18. Guedehoussou T, Tsolenyanu E, Djadou KE, Dossou A, Agbere AD, Atakouma DY, et al. Place des anemies dans la pathologie hospitaliere en pediatrie à l'hopital du district No III, hopital de Bè Lomé (Togo). J Rech Sci Univ Lomé. 2014;16(2):461-71.

19. Vaessen M, Thiam M, Lê T. Chapter XXII the demographic and health surveys. U N Stat Div U N Dep Econ Soc Aff. 2005.

20. Rutstein SO, Rojas G. Guide to DHS statistics: demographic and health surveys. methodology. 2006; https://dhsprogram.com/pubs/pdf/DHSG1/ Guide_to_DHS_Statistics_290ct2012_DHSG1.pdf (accessed 11 Feb 2018.

21. Maire B, Delpeuch F. Indicateurs de nutrition pour le développement: quide de référence. Disponible à l'adresse : http://www.fao.org/tempref/docrep/ fao/007/y5773f/y5773f00.pdf 2004.

22. Ewusie JE, Ahiadeke C, Beyene J, Hamid JS. Prevalence of anemia among under-5 children in the Ghanaian population: estimates from the Ghana demographic and health survey. BMC Public Health. 2014;14:626.

23. Ngesa $\mathrm{O}, \mathrm{Mwambi} \mathrm{H}$. Prevalence and risk factors of Anaemia among children aged between 6 months and 14 years in Kenya. PLoS One. 2014; 9(11):e113756.

24. Phillips RE, Pasvol G. Anaemia of Plasmodium falciparum malaria. Baillières Clin Haematol. 1992:5(2):315-30.

25. Owusu-Agyei S, Fryauff DJ, Chandramohan D, Koram KA, Binka FN, Nkrumah FK, et al. Characteristics of severe anemia and its association with malaria in young children of the Kassena-Nankana District of northern Ghana. Am J Trop Med Hyg. 2002;67(4):371-7.

26. Akhwale WS, Lum JK, Kaneko A, Eto H, Obonyo C, Björkman A, et al. Anemia and malaria at different altitudes in the western highlands of Kenya. Acta Trop. 2004:91(2):167-75.

27. Leite MS, Cardoso AM, Coimbra CE, Welch JR, Gugelmin SA, Lira PCl, et al. Prevalence of anemia and associated factors among indigenous children in Brazil: results from the first National Survey of indigenous People's health and nutrition. Nutr J. 2013;12(1):69.

28. Khanal V, Karkee R, Adhikari M, Gavidia T. Moderate-to-severe anaemia among children aged 6-59 months in Nepal: an analysis from Nepal demographic and health survey, 2011. Clin Epidemiol Glob Health. 2016:4(2):57-62.

29. Al-Qaoud NM, Al-Shami E, Prakash P. Anemia and associated factors among Kuwaiti preschool children and their mothers. Alex J Med. 2015;51(2):161-6. 
30. Morris SS, Ruel MT, Cohen RJ, Dewey KG, de la Brière B, Hassan MN. Precision, accuracy, and reliability of hemoglobin assessment with use of capillary blood. Am J Clin Nutr. 1999;69(6):1243-8.

31. Patel AJ, Wesley R, Leitman SF, Bryant BJ. Capillary versus venous

hemoglobin determination in the assessment of healthy blood donors. Vox Sang. 2013;104(4):317-23.

Ready to submit your research? Choose BMC and benefit from:

- fast, convenient online submission

- thorough peer review by experienced researchers in your field

- rapid publication on acceptance

- support for research data, including large and complex data types

- gold Open Access which fosters wider collaboration and increased citations

- maximum visibility for your research: over $100 \mathrm{M}$ website views per year

At $B M C$, research is always in progress.

Learn more biomedcentral.com/submissions 